\title{
Low Doses of Fenoxaprop-P-Ethyl Cause Hormesis in LitTleseed CANARYGRASS AND Wild OAT ${ }^{1}$
}

\author{
Hormesis Causada por Doses Reduzidas de Fenoxaprop-P-Ethyl em Erva-Cabecinha \\ e Aveia-Brava
}

ABBAS, T. ${ }^{2}$, NADEEM, M.A. ${ }^{2}$, TANVEER, A. ${ }^{2}$, and ZOHAIB, A. ${ }^{2}$

\begin{abstract}
Hormetic effects of herbicides at ultra-low doses have been proved against range of crop species, although available data of herbicides hormesis about the weeds growth is very limited. This study investigates the promotive effect of low doses of fenoxaprop-Pethyl on growth and seed production of littleseed canarygrass and wild oat. Pot experiments were conducted twice in Wire House at Agronomic Research Area, University of Agriculture, Faisalabad, during 2014-15. Seven different concentrations of fenoxaprop-P-ethyl [0, 1, 3, 6, 9, 12 and $15 \mathrm{~g}$ a.i. ha ${ }^{-1}$ ] were applied as post emergence herbicide at 3-4 leaves stage of the weeds. Results revealed that increase in growth occurred within first two weeks after spraying at fenoxaprop-P-ethyl doses 1,3 and $6 \mathrm{~g}$ a.i. ha ${ }^{-1}$. More growth stimulation as compared to all other treatments was observed at fenoxaprop-P-ethyl dose $6 \mathrm{~g}$ a.i. ha ${ }^{-1}$. This initial increase in growth sustains with time up to the maturity of both weeds and positively influences seeds production ability. Up to $28 \%$ and $17 \%$ increase in number of seeds per plants were occurred in littleseed canarygrass and wild oat, respectively. Doses above $6 \mathrm{~g}$ a.i. ha ${ }^{-1}$ negatively affect the weeds growth and seed production ability.
\end{abstract}

Keywords: Avena fatua, fenoxaprop-P-ethyl, growth stimulation, phalaris minor, ultra-low doses.

RESUMO - Os efeitos horméticos dos herbicidas em doses ultrarreduzidas foram comprovados em relação a uma série de espécies de culturas, embora os dados disponiveis relativos à hormesis dos herbicidas em relação ao crescimento de plantas daninhas sejam bastante limitados. Este estudo investiga o efeito promotor de doses reduzidas de fenoxaprop-P-ethyl sobre o crescimento e a produção de sementes de erva-cabecinha e aveia-brava. Experimentos em vasos foram realizados duas vezes na Wire House at Agronomic Research Area, Universidade de Agricultura, Faisalabad, durante 2014-15. Sete concentrações diferentes de fenoxaprop-P-ethyl [0, 1, 3, 6, 9, 12 e $15 \mathrm{~g}$ i.a. $\mathrm{ha}^{-1}$ ] foram aplicadas como herbicidas pós-emergência com as plantas daninhas no estágio de 3-4 folhas. Os resultados revelaram que houve um aumento no crescimento dentro das duas primeiras semanas após a aspersão de fenoxaprop-P-ethyl nas doses de 1, 3 e $6 \mathrm{~g}$ i.a. ha ${ }^{-1}$. Um estimulo maior do crescimento em comparação com todos os outros tratamentos foi observado para ofenoxaprop-P-ethyl na dose de $6 \mathrm{~g}$ i. a. $\mathrm{ha}^{-1}$. Esse aumento inicial do crescimento é mantido com o tempo até a maturação de ambas as plantas daninhas e influencia positivamente a capacidade de produção das sementes. Um aumento de até $28 \%$ e $17 \%$ no número de sementes por planta ocorreu para a erva-cabecinha e a aveia-brava, respectivamente. Doses acima de $6 \mathrm{~g}$ i. a. ha $\mathrm{h}^{-1}$ afetaram negativamente o crescimento das plantas daninhas e a capacidade de produção de sementes.

Palavras-chave: Avena fatua, fenoxaprop-P-ethyl, estímulo do crescimento, phalaris minor, doses ultrarreduzidas.

Recebido para publicação em 26.9.2015 e aprovado em 29.1.2016.

2 Department of Agronomy, University of agriculture, Faisalabad, 38040 (Pakistan), <tagondaluaf@gmail.com>. 


\section{INTRODUCTION}

The low dose growth stimulation phenomenon of herbicides is known as herbicide hormesis (Calabrese et al., 2007). Growth stimulation due to low doses of different herbicides has been shown in several crop species both in controlled and in the field conditions (Davies et al., 2003; Duke et al., 2006; Cedergreen et al., 2007; Velini et al., 2008). The literature revealed that herbicides at low doses cause on average $20-30 \%$ of growth stimulation under controlled conditions (Cedergreen et al., 2007) and 10-25\% under uncontrolled field conditions (Cedergreen et al., 2005, 2009). However, depending on the crop species, type of herbicide and other factors, this average stimulation increased up to $200 \%$ (Calabrese, 2008; Velini et al., 2008).

Littleseed canarygrass (Phalaris minor) and wild oat (Avena fatua) are two very problematic winter season annual weeds of cereals in Pakistan and are considered very troublesome and competitive weeds for wheat, barley and oat (Yasin et al., 2011). Among the herbicides commonly used to control these weeds, Fenoxaprop-P-ethyl, which is an ACCase inhibiting herbicide, is one of the most widely used herbicide in Pakistan. The literature revealed that fenoxaprop-P-ethyl produced growth stimulatory responses (hormesis) in weeds (Petersen et al., 2008). Up to 39\% of shoot growth stimulation has been observed due to hormetic effects of fenoxaprop-P-ethyl (Petersen et al., 2008).

Unintentionally, the herbicide hormesis under field conditions may appear due to herbicide drift, improper application method, improper time of application, dilution by dew drops and rain, weeds coverage by crop plants and/or mulches, herbicide dilution in soil by soil degradation and immobilization and herbicide resistance (Velini et al., 2010; Belz et al., 2011). This phenomenon occasionally becomes beneficial if crop plants are affected by hormetic effects (Velini et al., 2010). However, it may become unwanted and disturb the weed management if hormetic responses are produced in weeds. In an ecosystem context, growth stimulatory responses of herbicides may alter intra-weed and weed-crop competition. Plants that boost due to hormetic response may get competitive advantages over the plant species that are not or are adversely affected by that herbicide (Cedergreen, 2008b). It can also promote the growth of weeds grown on field borders and that received the drift dose of herbicides. Research addressing these issues is currently absent and the effects of herbicide hormesis on weed growth and weed crop competition are absent. Most of the published research is about the hormetic responses of crops against herbicides (Davies et al., 2003; Duke et al., 2006; Cedergreen et al., 2007; Velini et al., 2010; Belz et al., 2011). However, for practical implementation of herbicide hormesis to improve crop growth and yield, the effects of these lower doses on weed growth should also be considered. Research on responses of weeds to hormetic doses of herbicides may also help us to understand the evolution of the mechanism of resistance, because for resistant biotypes of weeds the recommended field doses of some herbicides may also act as hormetic doses and can produce hormetic responses (Petersen et al., 2008). Therefore, this study was conducted to evaluate the promotive effect of different lower doses of fenoxaprop-P-ethyl on the growth and seed production of littleseed canarygrass and wild oat.

\section{MATERIAL AND METHODS}

\section{Seed collection}

Fenoxaprop-P-ethyl susceptible seeds of littleseed canarygrass and wild oat were collected from the wheat field, which was previously not exposed to fenoxaprop-P-ethyl, during 2014. The collected seeds were separated, sun-dried, and stored in paper bags in room temperature. Before sowing the seeds, they were imbibed in distilled water for $24 \mathrm{~h}$ to promote germination (Om et al., 2004).

\section{Pot experiments}

To test hormetic responses of fenoxapropP-ethyl, pot studies were conducted twice in the green house, at the Agronomic Research Area, University of Agriculture, Faisalabad, Pakistan, during 2014-15. Ten seeds of both littleseed canarygrass and wild oat were sown separately in pots $(30 \mathrm{~cm}$ diameter and $45 \mathrm{~cm}$ 
depth). Soil was collected from the Agronomy Research Area, having no history of herbicide application and was mixed with farm yard manure $(2: 1, \mathrm{~W} / \mathrm{W})$. Water was regularly applied to keep the plant healthy. All pots were placed in the green house, and the mean minimum and maximum temperatures in the greenhouse during the experiment were $22{ }^{\circ} \mathrm{C}$ and $26^{\circ} \mathrm{C}$, respectively. The relative humidity ranged from 30-55\%. Completely Randomized Design (CRD) in factorial arrangement was used with four replicates. The pots were rearranged after each 4-5 days during the entire duration of the experiment to provide uniform conditions for the pots. Fenoxaprop-P-ethyl (Puma Super ${ }^{\circledR} 750$ EW, Bayer crop science, Pakistan) was used as postemergence herbicide at 3-4 leaves stage of weeds (growth stage normally used to control these weeds). Seven different concentrations of fenoxaprop-P-ethyl $(0,1,3,6,9,12$ and $15 \mathrm{~g}$ a.i. $\mathrm{ha}^{-1}$ ) were sprayed. FenoxapropP-ethyl was sprayed with a Knapsack hand sprayer fitted with flat fan nozzle at 30 psi pressure. Twenty one days after the fenoxaprop-P-ethyl application, data about shoot and root length, root volume, number of leaves, shoot and root dry weight was recorded. Five plants from each pot were selected randomly to record growth data and the remaining five plants were kept undisturbed for data collection at plant maturity. At the maturity stage, the plant height, root length, root volume, number of leaves, shoot and root dry weight, spike/panicle length and umber of seeds per plant were measured. The root volume of weeds was determined by water displacement (Harrington et al., 1994).

The data was analyzed using Fisher's Analysis of Variance. The least significant difference (LSD) at 5\% probability was applied to test the significance of the treatment means (Steel et al., 1997).

\section{RESULTS AND DISCUSSION}

\section{Stimulatory effect of Fenoxaprop-P-ethyl on the growth of littleseed canarygrass and wild oat two weeks after spraying}

The experiment was repeated twice. The results of the second experiment have been described in the text because the repeated experiment showed similar results. The results showed that fenoxaprop-P-ethyl doses between 1 to $6 \mathrm{~g}$ a.i. ha ${ }^{-1}$ positively influence the shoot length of both weeds, while the root length of both weeds were not affected by the treatments. The highest shoot length for both weeds was achieved in pots that were sprayed with $6 \mathrm{~g}$ a.i. ha-1, which was $21 \mathrm{~cm}$ for littleseed canarygrass and $29 \mathrm{~cm}$ for wild oat (Tables 1 and 2). The root volume was also positively influenced by the lower doses between 1 to $6 \mathrm{~g}$ a.i. ha ${ }^{-1}$. However, higher doses caused significant reduction in root volume as compared to control. The maximum root volume of $2.9 \mathrm{~cm}^{3}$ and $4.2 \mathrm{~cm}^{3}$ were observed for littleseed canarygrass and wild oat respectively at $6 \mathrm{~g}$ a.i. ha-1 (Tables 1 and 2). The shoot and root dry weight of both weeds

Table 1 - Stimulatory effect of Fenoxaprop-P-ethyl on the growth of littleseed canarygrass 15 days after spraying

\begin{tabular}{|c|c|c|c|c|c|c|}
\hline $\begin{array}{c}\text { Fenoxaprop-P-ethyl } \\
\text { doses }\end{array}$ & Shoot length & Root length & Root volume & $\begin{array}{l}\text { Shoot dry } \\
\text { weight }\end{array}$ & $\begin{array}{l}\text { Root dry } \\
\text { weight }\end{array}$ & \multirow{2}{*}{$\begin{array}{l}\text { No. of } \\
\text { leaves }\end{array}$} \\
\hline$\left(\right.$ g a.i. ha $\left.^{-1}\right)$ & \multicolumn{2}{|c|}{$(\mathrm{cm})$} & $\left(\mathrm{cm}^{3}\right)$ & \multicolumn{2}{|c|}{ (g) } & \\
\hline Control & $15.37 \mathrm{c}$ & 11.50 & $2.00 \mathrm{bc}$ & $0.27 \mathrm{~d}$ & $0.18 \mathrm{c}$ & $7.50 \mathrm{~b}$ \\
\hline 1 & $15.50 \mathrm{c}$ & 11.00 & $2.10 \mathrm{bc}$ & $0.41 \mathrm{c}$ & $0.17 \mathrm{~cd}$ & $7.00 \mathrm{bc}$ \\
\hline 3 & $18.00 \mathrm{~b}$ & 10.50 & $2.82 \mathrm{a}$ & $0.58 \mathrm{~b}$ & $0.23 \mathrm{~b}$ & $9.50 \mathrm{a}$ \\
\hline 6 & $21.50 \mathrm{a}$ & 10.75 & $2.95 \mathrm{a}$ & $0.66 \mathrm{a}$ & $0.28 \mathrm{a}$ & $9.25 \mathrm{a}$ \\
\hline 9 & $15.00 \mathrm{c}$ & 10.00 & $2.22 \mathrm{~b}$ & $0.25 \mathrm{~d}$ & $0.18 \mathrm{c}$ & $6.50 \mathrm{~cd}$ \\
\hline 15 & $12.50 \mathrm{~d}$ & 9.750 & $1.70 \mathrm{c}$ & $0.14 \mathrm{e}$ & $0.19 \mathrm{bc}$ & $5.75 \mathrm{~d}$ \\
\hline LSD & 1.1872 & NS & 0.4429 & 0.0338 & 0.0415 & 0.9760 \\
\hline
\end{tabular}

Means that do not share the same letters in a column are significantly different at a 0.05 probability level according to the Least Significance Difference test (LSD). 
Table 2 - Stimulatory effect of Fenoxaprop-P-ethyl on the growth of wild oat 15 days after spraying

\begin{tabular}{|c|c|c|c|c|c|c|}
\hline $\begin{array}{c}\text { Fenoxaprop-P-ethyl } \\
\text { doses }\end{array}$ & Shoot length & Root length & Root volume & $\begin{array}{l}\text { Shoot dry } \\
\text { weight }\end{array}$ & $\begin{array}{l}\text { Root dry } \\
\text { weight }\end{array}$ & \multirow{2}{*}{$\begin{array}{l}\text { No. of } \\
\text { leaves }\end{array}$} \\
\hline$\left(\right.$ g a.i. ha $\left.{ }^{-1}\right)$ & \multicolumn{2}{|c|}{$(\mathrm{cm})$} & $\left(\mathrm{cm}^{3}\right)$ & \multicolumn{2}{|c|}{ (g) } & \\
\hline Control & $18.45 \mathrm{c}$ & 14.58 & $3.13 \mathrm{~cd}$ & $0.37 \mathrm{~d}$ & $0.26 \mathrm{c}$ & $5.50 \mathrm{~b}$ \\
\hline 1 & $18.58 \mathrm{c}$ & 14.08 & $3.23 \mathrm{~cd}$ & $0.51 \mathrm{c}$ & $0.25 \mathrm{~cd}$ & $5.00 \mathrm{bc}$ \\
\hline 3 & $21.08 \mathrm{~b}$ & 12.93 & $3.75 \mathrm{~b}$ & $0.67 \mathrm{~b}$ & $0.31 \mathrm{~b}$ & $7.50 \mathrm{a}$ \\
\hline 6 & $24.58 \mathrm{a}$ & 13.18 & $4.20 \mathrm{a}$ & $0.76 \mathrm{a}$ & $0.36 \mathrm{a}$ & $7.25 \mathrm{a}$ \\
\hline 9 & $18.08 \mathrm{c}$ & 12.43 & $3.35 \mathrm{bc}$ & $0.35 \mathrm{~d}$ & $0.26 \mathrm{c}$ & $4.50 \mathrm{~cd}$ \\
\hline 15 & $15.58 \mathrm{~d}$ & 12.50 & $2.83 \mathrm{~d}$ & $0.24 \mathrm{e}$ & $0.27 \mathrm{bc}$ & $3.75 \mathrm{~d}$ \\
\hline LSD & 1.1872 & NS & 0.4062 & 0.0338 & 0.0415 & 0.9760 \\
\hline
\end{tabular}

Means that do not share the same letters in a column are significantly different at a 0.05 probability level according to the Least Significance Difference test (LSD).

also significantly increased at fenoxaprop-Pethyl doses between 1 to $6 \mathrm{~g}$ a.i. ha- ${ }^{-1}$. The higher doses (above $6 \mathrm{~g}$ a.i. ha ${ }^{-1}$ ) caused significant reduction in shoot and root dry weight. The highest shoot and root dry weight for both weeds was achieved in pots that were treated with fenoxaprop-P-ethyl at $6 \mathrm{~g}$ a.i. ha ${ }^{1}$, followed by those sprayed with fenoxaprop-Pethyl dose $3 \mathrm{~g}$ a.i. ha $\mathrm{h}^{-1}$ (Tables 1 and 2). The numbers of leaves per plant were significantly increased for both weeds at lower doses of fenoxaprop-P-ethyl, showing their hormetic responses (Tables 1 and 2). Results of all growth parameters (except root length) collected two weeks after spraying fenoxapropP-ethyl showed that fenoxaprop-P-ethyl caused growth stimulation at lower doses (1 to

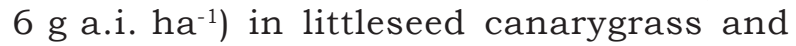
wild oat. The increase in different growth parameters due to fenoxaprop-P-ethyl is supported by the findings of Velini et al. (2008). Different herbicides have shown their promotive effect on the growth of a range of crop species and weeds at sub lethal doses (Duke et al., 2006; Velini et al., 2008).

\section{Stimulatory effect of Fenoxaprop-P-ethyl on the growth of littleseed canarygrass and wild oat at weed maturity}

The results of different growth parameters collected at weed maturity showed that lower doses of fenoxaprop-P-ethyl positively influence the growth of both studied weeds. Growth stimulation occurred at earlier growth stages sustained with time. The shoot length of both weeds showed significant elevation at fenoxaprop-P-ethyl doses between 1 to $6 \mathrm{~g} \mathrm{a}$.i. ha ${ }^{-1}$. The highest shoot length of $66 \mathrm{~cm}$ and $59 \mathrm{~cm}$ was observed for littleseed canarygrass and wild oat at $6 \mathrm{~g}$ a.i. harespectively (Tables 3 and 4). The root length of littleseed canarygrass showed no significant effect in relation to the treatments. However, the root length of wild oat significantly increased at lower doses, the maximum root length of $25 \mathrm{~cm}$ was observed in pots that were sprayed with fenoxaprop-P-ethyl at $6 \mathrm{~g}$ a.i. ha${ }_{1}^{1}$ (Tables 3 and 4). The root volume increased at lower doses of fenoxaprop-P-ethyl. The maximum root volume was observed at $6 \mathrm{~g}$ a.i. ha ${ }^{-1}$ for both weeds (Tables 3 and 4). The result of the shoot and root dry weight of littleseed canarygrass and wild oat showed that fenoxaprop-P-ethyl doses between 1 to $9 \mathrm{~g}$ a.i. $\mathrm{ha}^{-1}$ caused an increase in the dry weight. The maximum shoot (4 g) and root ( $\mathrm{g}$ ) dry weight for littleseed canarygrass was observed at a $3 \mathrm{~g}$ a.i. ha-1 herbicide dose, which was followed by $6 \mathrm{~g}$ a.i. ha ${ }^{-1}$. The maximum shoot (3.3 g) and root (2.8 g) dry weight in wild oat was observed at a $6 \mathrm{~g}$ a.i. ha $\mathrm{h}^{-1}$ herbicide dose, followed by the pots where a $3 \mathrm{~g}$ a.i. ha ${ }^{-1}$ dose was sprayed (Tables 3 and 4). The number of leaves calculated at maturity showed no significant effect of the treatments for wild oat (Tables 3 and 4). However, the total number of leaves of littleseed canarygrass was higher in pots treated with fenoxaprop-P-ethyl dose ranges between 1 to $6 \mathrm{~g}$ a.i. ha ${ }^{-1}$. The sustainability of promotive effect until plant maturity, which occurred within the first two weeks after spraying, is supported by the findings of Cedergreen (2008a). 
Table 3 - Stimulatory effect of Fenoxaprop-P-ethyl on the growth of littleseed canarygrass at plant maturity

\begin{tabular}{|c|c|c|c|c|c|c|}
\hline $\begin{array}{c}\text { Fenoxaprop-P-ethyl } \\
\text { doses }\end{array}$ & Shoot length & Root length & Root volume & $\begin{array}{c}\text { Shoot dry } \\
\text { weight }\end{array}$ & $\begin{array}{c}\text { Root dry } \\
\text { weight }\end{array}$ & $\begin{array}{c}\text { No. of } \\
\text { leaves }\end{array}$ \\
\hline \multicolumn{1}{|c|}{$\left(\mathrm{g} \mathrm{a.i.} \mathrm{ha}^{-1}\right)$} & \multicolumn{2}{|c|}{$(\mathrm{cm})$} & & \multicolumn{2}{|c|}{$(\mathrm{g})$} & \\
\hline Control & $54.75 \mathrm{~d}$ & 24.75 & $8.82 \mathrm{bc}$ & $2.78 \mathrm{c}$ & $2.30 \mathrm{~cd}$ & $12.25 \mathrm{ab}$ \\
\hline 1 & $59.58 \mathrm{bc}$ & 26.50 & $8.75 \mathrm{bc}$ & $3.37 \mathrm{ab}$ & $2.89 \mathrm{ab}$ & $12.50 \mathrm{a}$ \\
\hline 3 & $61.83 \mathrm{ab}$ & 26.00 & $14.37 \mathrm{a}$ & $3.59 \mathrm{a}$ & $3.21 \mathrm{a}$ & $13.75 \mathrm{a}$ \\
\hline 6 & $66.10 \mathrm{a}$ & 28.25 & $14.62 \mathrm{a}$ & $3.46 \mathrm{ab}$ & $2.91 \mathrm{ab}$ & $13.00 \mathrm{a}$ \\
\hline 9 & $55.55 \mathrm{~cd}$ & 27.25 & $8.25 \mathrm{bc}$ & $3.09 \mathrm{bc}$ & $2.62 \mathrm{bc}$ & $10.25 \mathrm{~b}$ \\
\hline 15 & $56.75 \mathrm{~cd}$ & 25.25 & $9.00 \mathrm{~b}$ & $2.28 \mathrm{~d}$ & $1.80 \mathrm{de}$ & $8.00 \mathrm{c}$ \\
\hline LSD & 4.6363 & $\mathrm{NS}$ & 2.2137 & 0.4389 & 0.5862 & 2.0610 \\
\hline
\end{tabular}

Means that do not share the same letters in a column are significantly different at a 0.05 probability level according to the Least Significance Difference test (LSD).

Table 4 - Stimulatory effect of Fenoxaprop-P-ethyl on the growth of wild oat at plant maturity

\begin{tabular}{|c|c|c|c|c|c|c|}
\hline $\begin{array}{c}\text { Fenoxaprop-P-ethyl } \\
\text { doses }\end{array}$ & Shoot length & Root length & Root volume & $\begin{array}{l}\text { Shoot dry } \\
\text { weight }\end{array}$ & $\begin{array}{l}\text { Root dry } \\
\text { weight }\end{array}$ & \multirow{2}{*}{$\begin{array}{l}\text { No. of } \\
\text { leaves }\end{array}$} \\
\hline$\left(\right.$ g a.i. $\left.\mathrm{ha}^{-1}\right)$ & \multicolumn{2}{|c|}{$(\mathrm{cm})$} & $\left(\mathrm{cm}^{3}\right)$ & \multicolumn{2}{|c|}{ (g) } & \\
\hline Control & $50.00 \mathrm{c}$ & $20.00 \mathrm{~b}$ & $11.02 \mathrm{~cd}$ & $2.55 \mathrm{c}$ & $2.07 \mathrm{bc}$ & $9.25 \mathrm{ab}$ \\
\hline 1 & $54.83 \mathrm{ab}$ & $21.75 \mathrm{ab}$ & $11.20 \mathrm{~cd}$ & $3.14 \mathrm{ab}$ & $2.71 \mathrm{a}$ & $9.50 \mathrm{a}$ \\
\hline 3 & $57.08 \mathrm{a}$ & $21.75 \mathrm{ab}$ & $16.32 \mathrm{ab}$ & $3.21 \mathrm{ab}$ & $2.73 \mathrm{a}$ & $10.75 \mathrm{a}$ \\
\hline 6 & $59.10 \mathrm{a}$ & $24.70 \mathrm{a}$ & $17.45 \mathrm{a}$ & $3.38 \mathrm{a}$ & $2.86 \mathrm{a}$ & $10.00 \mathrm{a}$ \\
\hline 9 & $50.80 \mathrm{bc}$ & $23.00 \mathrm{ab}$ & $13.70 \mathrm{bc}$ & $2.86 \mathrm{bc}$ & $2.39 \mathrm{ab}$ & $7.25 \mathrm{~b}$ \\
\hline 15 & $52.00 \mathrm{bc}$ & $20.50 \mathrm{~b}$ & $11.45 \mathrm{~cd}$ & $2.05 \mathrm{~d}$ & $1.57 \mathrm{~cd}$ & $5.00 \mathrm{c}$ \\
\hline LSD & 4.5889 & 3.8623 & 2.9794 & 0.4984 & 0.5718 & 2.0610 \\
\hline
\end{tabular}

Means that do not share the same letters in a column are significantly different at a 0.05 probability level according to the Least Significance Difference test (LSD).

\section{Stimulatory effect of lower doses of fenoxaprop-P-ethyl on spike/panicle length and number of seeds per plant of littleseed canarygrass and wild oat}

The results of littleseed canarygrass spike length showed that sub lethal doses of fenoxaprop-P-ethyl caused significant increase in spike length. Longer spikes $(6 \mathrm{~cm})$ were produced in pots that were sprayed with fenoxaprop-P-ethyl at $6 \mathrm{~g}$ a.i. ha ${ }^{-1}$, followed by pots sprayed with a $3 \mathrm{~g}$ a.i. ha ${ }^{-1}$ dose. Fenoxaprop-P-ethyl doses between 9 to $15 \mathrm{~g}$ a.i. ha ${ }^{-1}$ caused significant reduction in spike length (Figure 1A). Panicle length of wild oat was also significantly increased at $6 \mathrm{~g}$ a.i. ha ${ }^{-1}$ and followed by a $3 \mathrm{~g}$ a.i. ha ${ }^{-1}$ fenoxaprop-P-ethyl dose. Panicles with over $9 \mathrm{~cm}$ in length were produced in pots in which
$6 \mathrm{~g}$ a.i. ha- $\mathrm{h}^{-1}$ of herbicide was sprayed (Figure 1C). The results related to the seed production ability of both weeds showed that the seed number per plant increased significantly as fenoxaprop-P-ethyl doses increased from 1 to $6 \mathrm{~g}$ a.i. ha ${ }^{-1}$. Littleseed canarygrass treated with fenoxaprop-P-ethyl at $6 \mathrm{~g}$ a.i. ha ${ }^{-1}$ produced significantly more seeds per plant (204) than control (160). Littleseed canarygrass pots treated with $3 \mathrm{~g}$ a.i. ha ${ }^{-1}$ also produced a significantly higher number of seeds (179) than control pots. However, doses above $9 \mathrm{~g}$ a.i. ha ${ }^{-1}$ caused a reduction in the average seeds produced per plant (Figure 1B). The seed production ability of wild oat was also significantly increased at fenoxaprop-P-ethyl doses between 1 to $6 \mathrm{~g}$ a.i. ha ${ }^{-1}$. A significantly higher number of seeds (64) than the control (55) were produced in pots where a dose of 

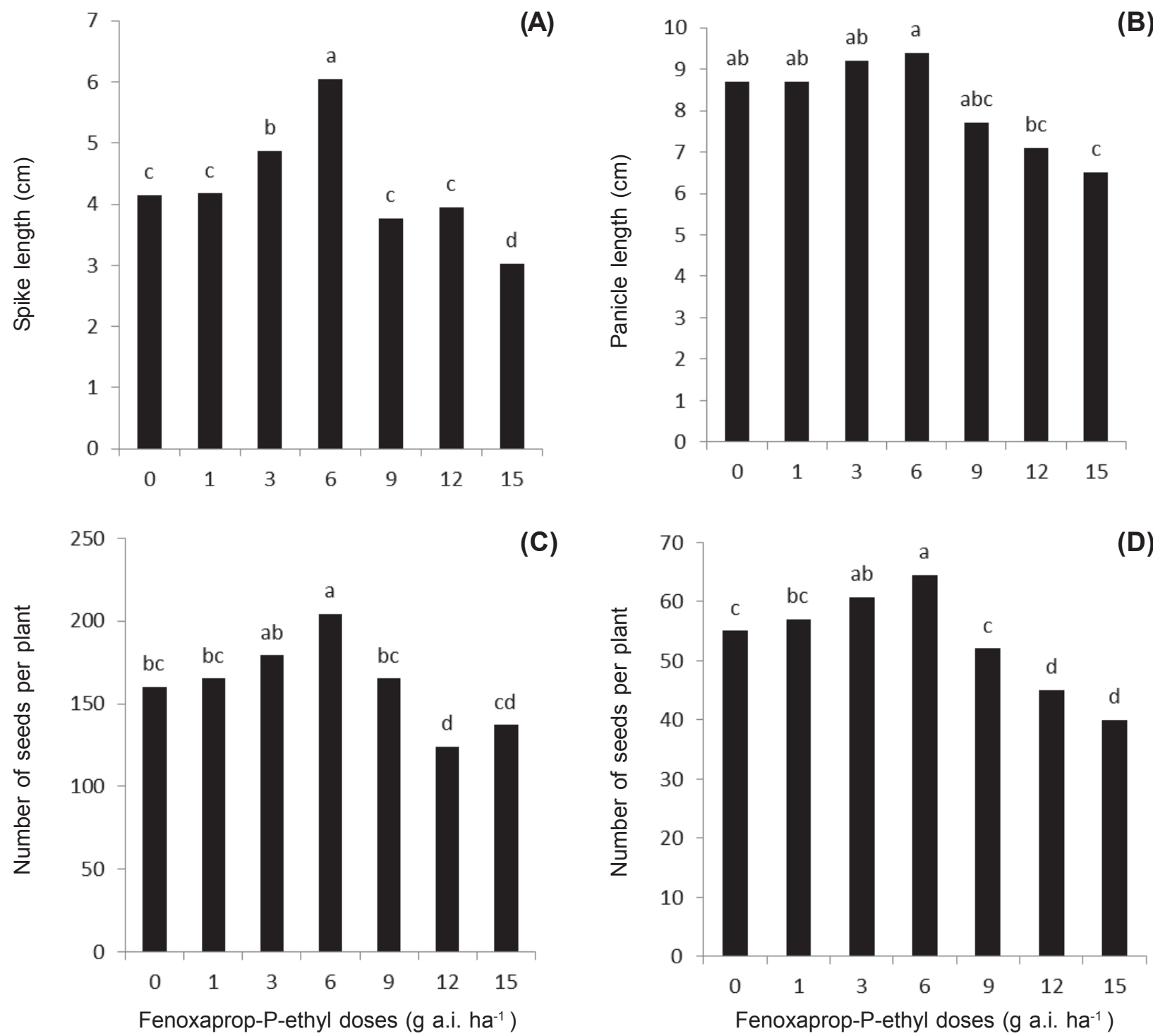

Treatment bars with common letters are not significantly different at the $5 \%$ probability level according to the Least Significance Difference test (LSD).

Figure 1 - Stimulatory effect of lower doses of fenoxaprop-P-ethyl on spike/panicle length and number of seeds per plant of littleseed canarygrass (A and C) and wild oat (B and D).

$6 \mathrm{~g}$ a.i. ha ${ }^{-1}$ of fenoxaprop-P-ethyl was sprayed. Fenoxaprop-P-ethyl at 12 and $15 \mathrm{~g}$ a.i. ha ${ }^{-1}$ dose caused significant reduction in the seed production ability of wild oat (Figure 1D). Different researches revealed that herbicide hormesis can cause an increase in grain yield and yield contributing parameters in crops (Duke et al., 2006; Cedergreen et al., 2008b).

According to these results, it can be concluded that the application of fenoxaprop-
P-ethyl at a dose ranging from 1 to $6 \mathrm{~g}$ a.i. ha ${ }^{-1}$ increased the vegetative growth of littleseed canarygrass and wild oat. The initial growth increase sustained up to maturity and improved seed production ability of both weeds. Therefore, it is suggested that fenoxaprop-Pethyl hormesis may influence the weed-crop competition by positively affecting the growth of littleseed canarygrass and wild oat plants exposed to lower doses of fenoxaprop-P-ethyl. This might be due to factors such as shade 
on crop plants, rain or dew drops after herbicide application and herbicide drift for weeds grown on field borders. This unwanted aspect of herbicide hormesis should be considered for practical implementation of herbicide hormesis to crop production and for establishing an effective weed management system.

\section{REFERENCES}

Belz R.G. et al. Herbicide hormesis- can it be useful in crop production? Weed Res. 2011:51:321-32..

Calabrese E.J., Blain R. Hormesis in plant biology. Environ Pollut. 2008;157:42-8.

Calabrese E.J. et al. Biological stress response terminology: integrating the concepts of adaptive response and preconditioning stress within a hormetic dose-response framework. Toxicol Appl Phar. 2007;222:122-8.

Cedergreen N. et al. Chemical stress can increase crop yield. Field Crops Res. 2009;114:54-7.

Cedergreen N. et al. Improved empirical models describing hormesis. Environ Toxicol Chem. 2005;24:3166-72.

Cedergreen N. et al. The occurrence of hormesis in plants and algae. Dose-Response. 2007:5:150-62.
Davies J. et al. Herbicide risk assessment for non-target aquatic plants: sulfosulfuron - a case study. Pest Manage Sci. $2003 ; 59: 231-7$.

Duke S.O. et al. Hormesis: is it an important factor in herbicide use and allelopathy? Outlooks Pest Manage. 2006;17:29-33.

Harrington J.T. et al. Volume displacement provides a quick and accurate way to quantify new root production. Tree Plant Notes. 1994;45:121-4.

Om H. et al. Biology and management of Phalaris minor in rice wheat system. Crop Protec. 2004;23:1157-68.

Petersen J. et al. Resistant factors of target-site and metabolic resistant black-grass (Alopecurus myosuroides Huds.) biotypes against different ACC-ase-inhibitors. J Plant Dis Protect. 2008;21:S25-S30.

Steel R.G.D. et al. Principles and procedures of statistics: a biometrical approach. 3rd. ed. New York: McGraw Hill Book, 1997. p.172-7.

Velini E.D. et al. Growth regulation and other secondary effects of herbicides. Weed Sci. 2010;58:351-4.

Velini E.D. et al. Glyphosate applied at low doses can stimulate plant growth. Pest Manage Sci. 2008;64:489-96.

Yasin M., Iqbal Z. Chemical control of grassy weeds in wheat (Triticum aestivum L.). Germany: Lap Lambert Academic Publication, 2011. 76p. 